\title{
MOLECULAR IDENTIFICATION AND CHARACTERISATION OF ASPERGILLUS FLAVUS ISOLATES ORIGINATING FROM SERBIAN WHEAT GRAINS
}

\author{
J. Krulja*, N. ĆurČića ${ }^{a}$, A. Bočarov Stančić ${ }^{b}$, J. Kojića, L. Pezo , L. Peić TukuljaC \\ and M. BODROŽA SOLAROV ${ }^{a}$ \\ anstitute of Food Technology Novi Sad, University of Novi Sad, Bul. cara Lazara 1, 21000 Novi Sad. Serbia \\ ${ }^{\mathrm{b}}$ Institute for Science Application in Agriculture, Bulevar despota Stefana 68B, \\ 11000 Belgrade. Serbia \\ ${ }^{\mathrm{c}}$ Institute of General and Physical Chemistry, University of Belgrade, Studentski Trg 12 - 16, 11000 Belgrade. \\ Serbia
}

(Received: 20 February 2020; accepted: 29 June 2020)

\begin{abstract}
During previous years, regarding the shifts in climate conditions in temperate region, such as occurrence of high temperatures and prolonged drought, increased occurrence frequencies of Aspergillus flavus and aflatoxins in cereal grains were recorded. A reliable and accurate identification of the fungi is of great importance for evaluating the microbiological risks of contamination. The essential point of the present investigation was molecular characterisation and identification of $A$. flavus isolates originating from common wheat and spelt grains collected after harvest during the period of three years (2015-2017) in Northern Serbia. A holistic approach that included PCR amplification of two DNA genomic regions and PCR-RFLP assay followed by fragment length analysis, provided complete and comprehensive characterisation of A. flavus isolated from wheat grains. The presented results indicate that there was no difference among the tested Aspergillus isolates on the molecular-genetic level. All 38 strains were identified as A. flavus by sequencing of combined ITS region and $\beta$-tubulin gene fragments (acc. no.: MH582473 to MH582510). PCR-RFLP method in combination with a Lab-on-a-chip (LoaC) electrophoresis can be successfully used to rapidly identify A. flavus isolates.
\end{abstract}

Keywords: wheat, A. flavus, molecular characterisation, PCR, RFLP

Wheat (Triticum aestivum L.) is a widely cultivated cereal in Serbia, with average production of approximately $4.3 \mathrm{t} \mathrm{ha}^{-1}$ in the period from 2015 to 2017 (Statistical Yearbook of the Republic of Serbia, 2018). The main growing area for wheat production in Serbia is Vojvodina (Northern Province of Serbia), where average total production of wheat for the mentioned three-year period amounted to $1526425 \mathrm{t}$. In the recent years, an ancient wheat subspecies - spelt (Triticum aestivum ssp. spelta L. Thell) - has received growing production interest due to its superior nutritional and pro-health properties.

According to IARC classification, aflatoxins are in the first group as carcinogen compounds for humans and animals (IARC, 2002). Aspergillus flavus and associated toxins have occurred mainly on maize in temperate regions of Serbia when the weather conditions were dry and warm (Kos et al. , 2013; JANIĆ-HAJNAL et al., 2017). However, a high incidence of A. flavus (45.8\%) on wheat was recorded in 2012 as the result of high temperatures and extreme dry conditions during the summer (Lević et al., 2013). Two A. flavus isolates collected from wheat in 2015 have shown the potential for aflatoxin $\mathrm{B}_{1}$ biosynthesis (KRULJ

* To whom correspondence should be addressed.

E-mail: jelena.krulj@fins.uns.ac.rs 
et al., 2016). The recent study indicated the occurrence of A. flavus on spelt wheat in Serbia after harvest in 2016 (KRULJ et al., 2017). Comparing the resistance of different wheat species, spelt wheat showed the strongest response to the artificial field infection with $A$. flavus and $\mathrm{AFB}_{1}$ biosynthesis (KRULJ et al., 2018). Therefore, there is a potential for the occurrence of these fungi and their toxins in cereals such as wheat, which can pose health hazards to humans and animals.

Reliable and accurate identification of the fungi has a great importance for facilitating better assessment of contamination. Classical morphological-based methods for identification and distinguishing of the main toxigenic fungi occurring in foods and feeds present numerous confinements, such as labour-demanding aspects and significant specialised aptitude. Taking into account that morphological characters could be very volatile depending on the media and culture properties, misclassification of fungal species including Aspergillus spp. based on morphological attributes is not unusual (WANG et al., 2001). Therefore, most identification methodologies are now based on DNA detection by using polymerase chain reaction (PCR) methods. The ITS region is considered to be a universal and primary molecular marker for identification of fungi (WHITE et al., 1990). However, each genus has its own specificity, and within the genus Aspergillus, calmodulin and $\beta$-tubulin genes are often used as secondary molecular markers (RoDRIGUES et al., 2007). $\beta$-tubulin is a conserved gene, which provides a high level of interspecies variability, consequently it is often used for phylogenetic studies of Aspergillus (Peterson, 2008). SAmson and VARGa (2009) suggested at least two genomic sequences for the description and identification of the species using a multilocus approach.

PCR-restriction fragment length polymorphism (PCR-RFLP) is a simple, cost effective and quick tool for rapid detection of specific differences in DNA sequences of Aspergillus species (SomasheKar et al., 2004).

The subject of the present research was a molecular characterisation of 38 A. flavus isolates from common wheat and spelt grains collected during the three-year period (20152017) in Northern Serbia. Molecular approaches, based on PCR amplification of individual and combined sequences of ITS and $\beta$-tubulin, then PCR-RFLP method followed by the fragment length analysis, provide complete and comprehensive characterisation of $A$. flavus isolated from wheat grains.

\section{Materials and methods}

\subsection{Isolates}

A. flavus cultures isolated from common wheat and spelt grain samples were collected during the three-year period (2015-2017) in Northern Serbia. Aspergillus cultures, purified by the single spore method and developed on potato dextrose agar (PDA), were afterwards grown on Czapek-Dox agar (CDA) medium at $25^{\circ} \mathrm{C}$ for 7 days. On Aspergillus flavus and parasiticus agar (AFPA), specific medium for the identification of species from Flavi group, cultivations of the isolates were done at $30{ }^{\circ} \mathrm{C}$ for 3 days (Piтt et al., 1983). A. flavus isolates were first identified by morphology (microscopic and macroscopic characteristics of the colonies) based on descriptions of KLICH (2002) and SAMSON and co-workers (2010).

\subsection{Molecular identification of the isolates}

Complete genomic DNA was extracted from mycelia using the DNA Isolation Kit (Agilent Technologies, Santa Clara, CA). The rDNA-ITS region was amplified applying the universal 
fungal primers ITS1 and ITS4 (White et al., 1990). $\beta$-tubulin, a gene specific for the identification of Aspergillus species, is amplified by the pair of $\mathrm{Bt} 2 \mathrm{a} / \mathrm{Bt} 2 \mathrm{~b}$ primers, as well as by AflaFor/Bt2b. PCR was performed in a thermal cycler (Sure Cycles 8800; Agilent Technologies, Santa Clara, CA, USA) programmed for the appropriate cycling parameters (NASRI et al., 2015; BAROŠEvIĆ et al., 2016). Amplified PCR products were purified using silica-membrane-based columns of the QIA quick PCR Purification kit (Qiagen, Chadstone, Australia) as indicated by the manufacturer's guidelines. After purification, DNA fragments were measured by the Agilent Bioanalyzer 2100 with LabChip DNA1000 (Agilent Technologies, CA, USA). Purified rDNAs, amplified by AflaFor/Bt2b, were sequenced and identified using BLAST programs at NCBI database.

\subsection{Restriction enzyme digestion}

The PCR products, amplified by the primers ITS1/ITS4, were digested with the HhaI and MwoI (HpyF10VI) enzymes (Thermo Scientific, USA). Digestion was performed by incubating a $10 \mu \mathrm{l}$ aliquot of PCR product with $2 \mu 1$ of $10 \times$ Fast Digest buffer and $1 \mu 1$ of Fast Digest enzyme, in a final reaction volume of $30 \mu 1$. Incubation was performed at $37^{\circ} \mathrm{C}$ for $10 \mathrm{~min}$. The digestion was heat-terminated at $80^{\circ} \mathrm{C}$ for $20 \mathrm{~min}$ after incubation performed with MwoI, while the thermal inactivation to PCR products digested with the HhaI was not applied. The amplicons of $\beta$-tubulin gene (primers $\mathrm{Bt} 2 \mathrm{a} / \mathrm{Bt} 2 \mathrm{~b}$ ) were digested with $A l w \mathrm{I}$ (BspPI) enzyme (Thermo Scientific, USA) for $4 \mathrm{~h}$ at $55^{\circ} \mathrm{C}$ and heat-terminated at $80^{\circ} \mathrm{C}$ for $20 \mathrm{~min}$. The reaction mixture contained $10 \mu \mathrm{l}$ of PCR amplicons, $2 \mu \mathrm{l}$ of $10 \times$ Buffer Tango, $1 \mu 1$ of AlwI (BspPI) restriction enzyme, and $18 \mu 1$ nuclease free-water. Visualisation of the restriction fragments was carried out by capillary electrophoresis at Agilent Bioanalyzer 2100 with Lab Chip DNA1000 (Agilent Technologies, CA, USA).

All above mentioned analyses performed on the tested isolates were carried out parallel to the A. flavus ATCC ${ }^{\circledR} 9643$ reference strain in order to compare and confirm the identification.

\section{Results and discussion}

A. flavus isolates were first identified according to the macroscopic and microscopic morphological characteristics of their colonies (KLICH, 2002). AFPA (Aspergillus flavus and parasiticus agar) and CDA (Czapek-Dox agar) were used as specific media for A. flavus identification. AFPA (Aspergillus flavus and parasiticus agar) is a selective medium for the rapid identification of Aspergillus of section Flavi (PIтT et al., 1983). The possibility of distinguishing Aspergillus species from the Flavi section is based on intense orange colony reverse when grown on AFPA. An intense orange colour was observed for all tested isolates (Figs 1A and 1B). None of the isolates showed a cream or brown reverse side on AFPA, which would correspond to A. oryzae and A. tamarii species, respectively (RoDRIGUEs et al., 2009). The conidia ornamentation and colour of the colonies on Czapek-Dox agar (CDA) were important features in identification. In this study, A. flavus colonies grown on CzapekDox agar were yellow-green (Figure 1C), while the colour of A. parasiticus colonies was dark green (KLICH, 2002). All yellow-green colonies had finely rough, round to elliptical conidia with thin walls, while dark green colonies showed extremely rough, more spherical conidia of thicker walls. These criteria have been applied as important principles for differentiation of A. flavus and A. parasiticus. 


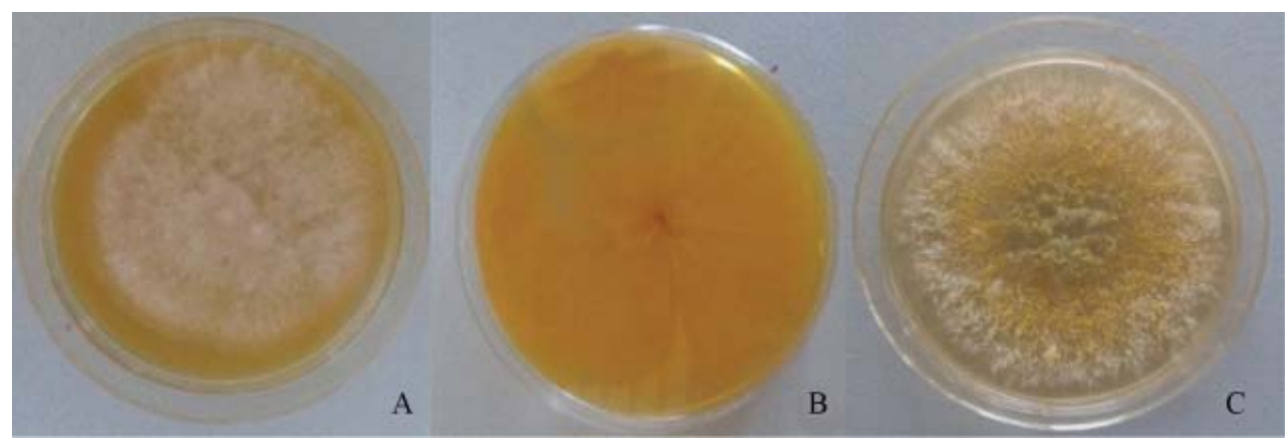

Fig. 1. A. flavus on: AFPA ( 3 days, $\left.30^{\circ} \mathrm{C}\right)$ : A: colony surface; B: colony reverse; C: CDA $\left(7\right.$ days, $\left.25^{\circ} \mathrm{C}\right)$. AFPA: Aspergillus flavus and parasiticus agar; CDA: Czapek-Dox agar

Taxonomically, A. flavus conidia are mostly produced from heads bearing both metulae and phialides, while the most heads of A. parasiticus bear phialides alone (KLICH, 2002).

In general, morphological features are still widely used for identification of Aspergillus spp. This method is commonly used and is an essential tool for categorisation of fungal isolates in groups or sections, that allows further identification by other methods. Regardless of the morphological characteristics defined, this study has found variations within the $A$. flavus species related to the shade of colour, the structure of the colonies, and the possibility of forming sclerotia during the cultivation of isolates under the same conditions (Fig. 2).

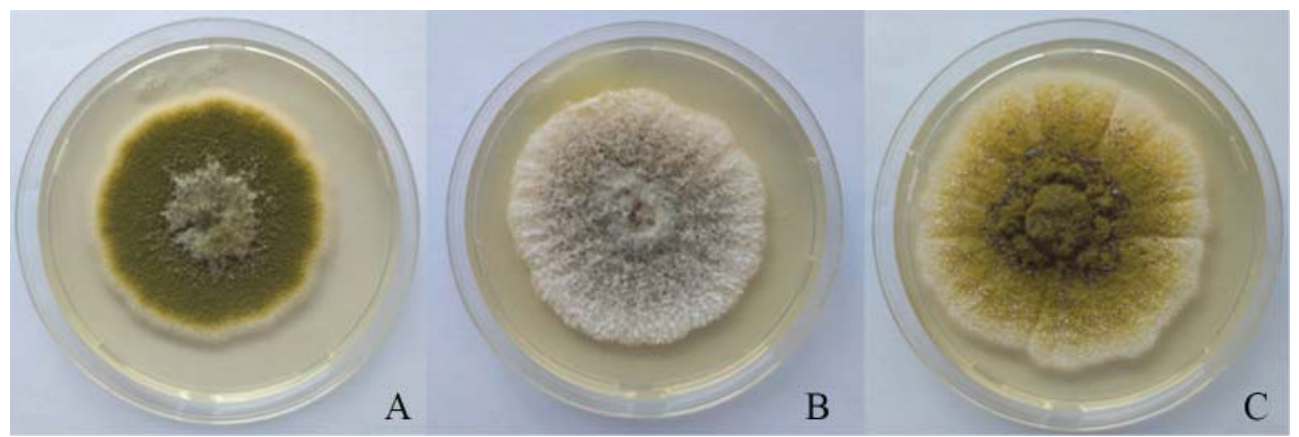

Fig. 2. Colony morphology of A. flavus isolates (PDA, 7 days, $25^{\circ} \mathrm{C}$ ) A: ATCC $(9643$ reference strain, B: isolate Acc.No. MH582473, C: isolate Acc.No. MH582474; PDA: potato dextrose agar

Since the classical microbiological identification methods did not completely enable the precise and clearly defined classification of A. flavus, the implementation of molecular methods was necessary for the reliable and accurate identification of the tested isolates.

After DNA extraction from tested A. flavus isolates, PCR reactions were conducted with different primer pairs: ITS1/ITS4, AflaFor/Bt2b, and Bt2a/Bt2b. The products of the PCR reactions amplified by the pair of primers AflaFor/Bt $2 \mathrm{~b}$ were purified and sequenced. The nucleotide sequences have been submitted to the GenBank (accession numbers: MH582473 to MH582510). BLAST analysis showed that sequences from $38 \mathrm{~A}$. flavus isolates shared $99 \%$ nucleotide identity with $A$. flavus species available from the GenBank database. 
The fragment size obtained by PCR reaction with primers ITS1/ITS4 was $600 \mathrm{bp}$ for all isolates, as well as the reference strain, which corresponds to the results of DIBA and coworkers (2014). The fragment size obtained by PCR reaction using the primer pair AflaFor/ Bt2b was $447 \mathrm{bp}$, while the fragment size amplified by the primers Bt2a/Bt2b was 565 bp (Table 1). Those results were in accordance with studies of NASRI and co-workers (2015) and BAROŠEVIĆ and co-workers (2016).

Table 1. Reference and obtained fragment sizes of PCR products amplified by the different primer pairs

\begin{tabular}{|c|c|c|c|c|c|}
\hline \multirow{2}{*}{$\begin{array}{l}\text { Primers } \\
\text { ITS1 }\end{array}$} & \multirow{2}{*}{$\begin{array}{l}\text { Gen } \\
\text { ITS region }\end{array}$} & \multirow{2}{*}{$\begin{array}{l}\text { Sequences of primers } \\
\text { 5'-TTCGTAGGTGAACCTGCGG-3' }\end{array}$} & \multicolumn{2}{|c|}{ Reference fragment size } & \multirow{3}{*}{$\begin{array}{c}\begin{array}{c}\text { Obtained } \\
\text { fragment } \\
\text { size }\end{array} \\
600\end{array}$} \\
\hline & & & \multirow{2}{*}{$600 \mathrm{bp}^{\dagger}$} & \multirow{2}{*}{$\begin{array}{l}\text { White et al., } \\
1990\end{array}$} & \\
\hline ITS4 & & 5'-TCCTCCGTCTATTGATATGC-3' & & & \\
\hline AflaFor & ITS region/ & 5'- GTGTCCTGTTATATCTGCCACAT -3' & \multirow[t]{2}{*}{-} & \multirow{2}{*}{$\begin{array}{l}\text { BAROŠEVIĆ et } \\
\text { al., } 2016\end{array}$} & \multirow[t]{2}{*}{447} \\
\hline $\mathrm{Bt} 2 \mathrm{~b}$ & $\beta$-tubulin & 5'- ACCCTCAGTGTAGTGACCCTTGGC -3' & & & \\
\hline $\mathrm{Bt} 2 \mathrm{a}$ & $\beta$-tubulin & 5'-GGTAACCAAATCGGTGCTGCTTTC-3' & \multirow[t]{2}{*}{$550 \mathrm{bp}$} & \multirow{2}{*}{$\begin{array}{l}\text { NASRI et al., } \\
2015\end{array}$} & \multirow[t]{2}{*}{565} \\
\hline Bt2b & & 5'- ACCCTCAGTGTAGTGACCCTTGGC -3' & & & \\
\hline
\end{tabular}

†bp: base pair

The presented results indicated that there was no difference among the tested Aspergillus isolates on the molecular-genetic level. The separation of amplified PCR products of different A. flavus strains by Lab-on-a-chip electrophoresis was confirmed by sequencing. Therefore, the PCR method in combination with the Lab-on-a-chip electrophoresis can be successfully used for rapid differentiations of Aspergillus species.

Several studies have shown that the PCR-RFLP method might be valuable for the identification of numerous fungal species (SomasheKar et al., 2004; Atoui \& El Khoury, 2016). The digestion of PCR products performed by the use of restriction enzymes HhaI, MwoI, and AlwI, resulted in a number of fragments of characteristic sizes (Fig. 3). Gel image for AlwI is not shown. According to the fragment analysis, there are three restriction places for HhaI in the sequence of A. flavus that separated the PCR products into four fragments of $200 \mathrm{bp}, 194 \mathrm{bp}, 163 \mathrm{bp}$, and $112 \mathrm{bp}$. Also, the restriction enzyme MwoI was managed to cut the PCR product of $A$. flavus at three places resulting in four fragments of $318 \mathrm{bp}, 115 \mathrm{bp}, 81$ $\mathrm{bp}$, and $51 \mathrm{bp}$. Contrary to that, there was only one restriction place for AlwI in the sequence of A. flavus yielding two fragments of $287 \mathrm{bp}$ and $245 \mathrm{bp}$. NASRI and co-workers (2015) claimed that $\beta$-tubulin gene digestion, due to its own specificity, allowed a more discriminating RFLP assay for species distinction of clinically important Aspergillus spp.

Digestion of the PCR products by the use of restriction enzymes produced same patterns of fragments among the isolates revealing genetic similarity. By comparing the number and the fragment size of the tested isolates with the profile of reference strain obtained by digestion with the same enzymes, it can be concluded that differences were not observed. A. flavus and A. parasiticus have shown to possess high degree of genetic similarity and related genome size. Minor nucleotide variations in DNA sequence can be detected by PCRRFLP analyses (Aтоu \& El KhourY, 2016). Regarding literature data, the use of restriction enzymes indicated the possibility of clear distinguishment of A. parasiticus and A. flavus. Analysis of RFLP products in agarose gel showed restriction profiles that clearly showed differences both in the number of fragments and in their size between the analysed samples 
of these two species (SomasheKar et al., 2004; Atoui \& El Khoury, 2016). Study of MIRHENDI and co-workers (2007) showed that the size of PCR fragments amplified by ITS1/ ITS4 primers prior to digestion was $595 \mathrm{bp}$, which corresponds to the results obtained in this study (600 bp). On the other hand, the size of the fragments obtained after digestion with the HhaI enzyme according to the studies of these authors were 184 bp, 179 bp, 143 b,p and 89 bp. Differences in the size of fragments obtained using the same enzyme can be due to the application of different methods of electrophoresis. The same authors (MIRHENDI et al., 2007) applied the agarose gel electrophoresis for separation of the PCR products, while in our tests separation was performed with Lab-on-a-chip electrophoresis. Similar differences were observed in the application of the MwoI when comparing the results of our tests with the results of DiBA and co-workers (2014), who tested the possibility of using this enzyme for identification and molecular characterisation of medically important Aspergillus species. Study of NASRI and co-workers (2015) obtained the RFLP profile of AlwI with two fragments (296 bp and $254 \mathrm{bp}$ ) for used reference strains and investigated isolates. In this investigation, identification of $A$. flavus isolates based on RFLP assay of ITS region and $\beta$-tubulin gene was absolutely in accordance with sequencing pattern and results based on morphological criteria.

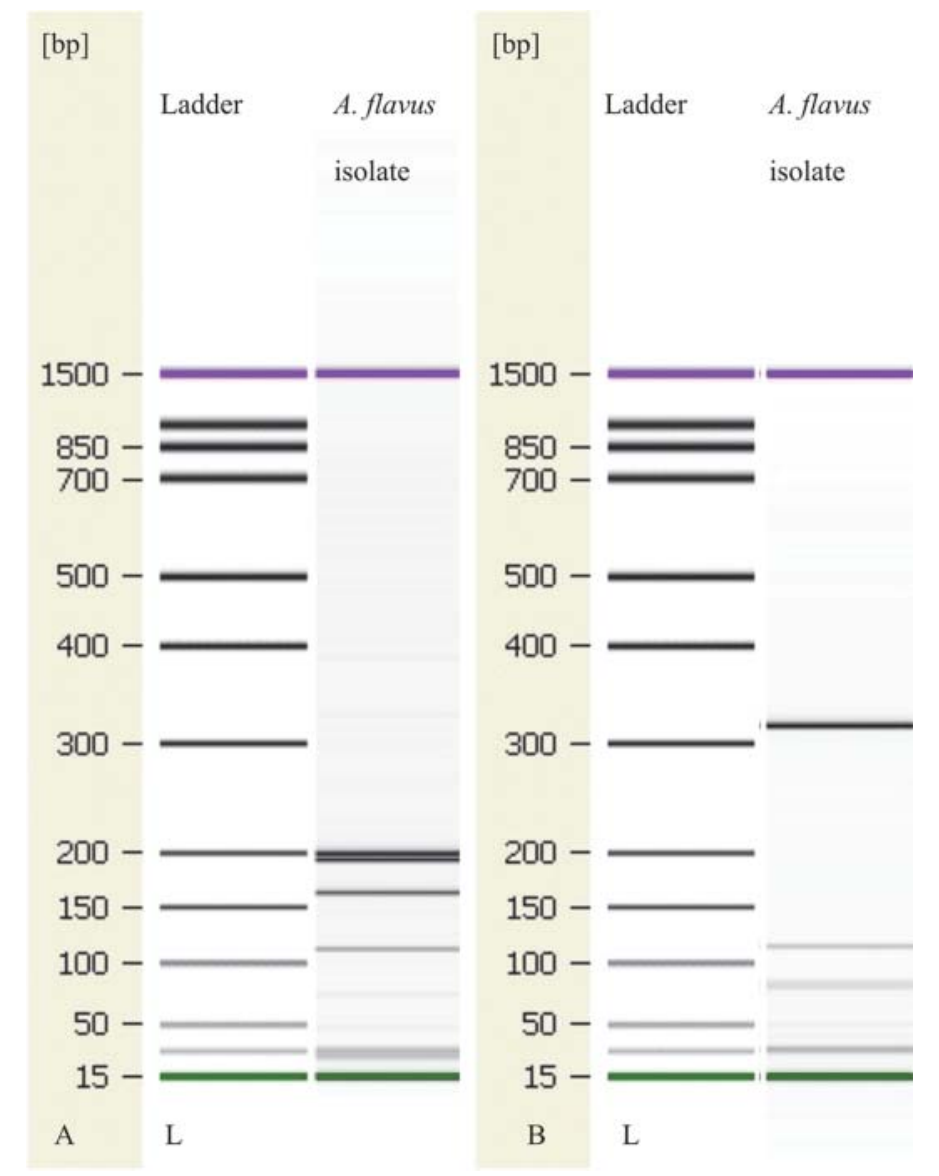

Fig. 3. Gel image of the electrophoretically separated PCR products digested with restriction enzymes: A: HhaI-RFLP of ITS-PCR products; B: MwoI-RFLP of ITS-PCR products; L: 25-1000 bp DNA ladder. Fragments labelled with $15 \mathrm{bp}$ and $1500 \mathrm{bp}$ are internal calibration markers 
By comparing the phenotypic grouping of the isolates using colony colour on AFPA and CDA and conidia ornamentation with the molecular identification achieved by the $\beta$-tubulin and ITS sequence analysis and PCR-RFLP analysis, we could observe that the two approaches are complementary to one another.

\section{Conclusions}

Molecular methods are gaining increased significance in species identification due to their high sensitivity, specificity, reproducibility, and performance speed. PCR-RFLP assay, as an effective, reliable, and quick method, gives the opportunity for faster identification and differentiation of the Aspergillus species than standard culturing methods and conventional sequencing of PCR products. In order to provide a more holistic approach, molecular characterisation of 38 Aspergillus isolates obtained from wheat and spelt grains over the three-year period in Northern Serbia was done. All analysed isolates were identified as A. flavus - the main agent responsible for aflatoxin contamination of cereals and other crops. So far, there is no report of aflatoxin contamination of wheat in Serbia. Nevertheless, the occurrence of toxigenic species such as A. flavus in the present study suggested that there is the potential risk of aflatoxin contamination of wheat grains used for the production of wheatbased food products.

This study was funded by the Ministry of Education, Science and Technological Development of the Republic of Serbia (451-03-68/2020-14/200222).

\section{References}

Atoui, A. \& El Khoury, A. (2016): PCR-RFLP for Aspergillus species. Mycotoxigenic Fungi, 313-320.

Barošević, T., Bagi, F., Budakov, D., Kocsubé, S., VArga, J., .. \& \& Stojšin, V. (2016): Molecular and morphological identification of Aspergillus species on corn seeds. Proceedings of the III International Congress, "Food Technology, Quality and Safety”; October 25-27, 2016; Novi Sad; Serbia, pp. 365-371.

Diba, K., Mirhendi, H., Kordbacheh, P. \& Rezaie, S. (2014): Development of RFLP-PCR method for the identification of medically important Aspergillus species using single restriction enzyme MwoI. Braz. J. Microbiol., 45, 503-507.

IARC (2002): Monograph on the evaluation of carcinogenic risk to humans, vol. 82. World Health Organization, International Agency for Research on Cancer IARC, Lyon, France. p. 171.

Janić-Hajnal, E., Kos, J., Krulu, J., Krstović, S., Jajić, I., .. \& \& NedelJKović, N. (2017): Aflatoxins contamination of maize in Serbia: The impact of weather conditions in 2015. Food Addit Contam, A, 34, 1999-2010.

KLICH, M.A. (2002): Identification of common Aspergillus species. Centraal bureau voor Schimmel cultures, Utrecht. 116 pages.

Kos, J., Mastilović, J., Hajnal, E.J. \& ŠArić, B. (2013): Natural occurrence of aflatoxins in maize harvested in Serbia during 2009-2012. Food Control, 34, 31-34

Krulj, J., Bočarov Stančić, A., Krstović, S., Kojić, J., Đisalov, J., ... \& Bodroža-Solarov, M. (2016): Toxigenic potential of Aspergillus flavus cultures isolated from wheat grains. Proceedings of the III International Congress "Food Technology, Quality and Safety"; October, 27-29, 2016. Novi Sad, Serbia, $418-423$.

Krulu, J., Đisalov, J., Bodroža-Solarov, M., Bočarov Stančić, A., Markov, S., .... \& Kojić, J. (2017): First report of Aspergillus flavus on organic spelt wheat in Serbia. Plant Dis., 101, 1045-1045.

Krulj, J., Đisalov, J., Bočarov Stančić, A., Pezo, L., Kojić, J., ... \& Bodroža Solarov, M. (2018): Occurrence of aflatoxin B1 in Triticum species inoculated with Aspergillus flavus. World Mycotoxin J., 11, 247-257. 
Lević, J., Gošić-Dondo, S., Ivanović, D., Stanković, S., Krnjaja, V., ... \& Stepanić, A. (2013): An outbreak of Aspergillus species in response to environmental conditions in Serbia. Pestic. Phytotomed. Belgrade, 28, $167-179$.

Mirhendi, H., Diba, K., Kordbacheh, P., Jalalizand, N. \& Makimura, K. (2007): Identification of pathogenic Aspergillus species by a PCR-restriction enzyme method. J. Med. Microbiol., 56, 1568-1570.

Nasri, T., Hedayati, M.T., Abastabar, M., Pasqualotto, A.C., Armaki, M.T., ... \& Nabili, M. (2015): PCR-RFLP on $\beta$-tubulin gene for rapid identification of the most clinically important species of Aspergillus. J. Microbiol. Meth., 117, 144-147.

Peterson, S.W. (2008): Phylogenetic analysis of Aspergillus species using DNA sequences from four loci. Mycologia, 100, 205-226.

Pitt, J.I., Hocking, A.D. \& GlenN, D.R. (1983): An improved medium for the detection of Aspergillus flavus and A. parasiticus. J. Appl. Bacteriol., 54, 109-114.

Rodrigues, P., Soares, C., Kozakiewicz, Z., Paterson, R.R.M., Lima, N. \& VenÂncio, A. (2007): Identification and characterization of Aspergillus flavus and aflatoxins. -in: Mendez-VILAS, A. (Ed.) Communicating current research and educational topics and trends in applied microbiology. Bajadoz, Formatex. pp. 527-534.

Rodrigues, P., VenÂncio, A., Kozakiewicz, Z. \& Lima, N. (2009): A polyphasic approach to the identification of aflatoxigenic and non-aflatoxigenic strains of Aspergillus section Flavi isolated from Portuguese almonds. Int. J. Food Microbiol., 129(2), 187-193.

SAMSON, R.A. \& VARGA, J. (2009): What is a species in Aspergillus? Med. Mycol., 47, S13-S20.

Samson, R.A., Houbraken, J., Thrane, U., Frisvad, J.C. \& Andersen, B. (2010): Food and indoor fungi. CBS KNAW Biodiversity Center, Utrecht. 390 pages.

Somashekar, D., Rati, E.R. \& Chandrashekar, A. (2004): PCR-restriction fragment length analysis of aflR gene for differentiation and detection of Aspergillus flavus and Aspergillus parasiticus in maize. Int. J. Food Microbiol., 93, 101-107.

Statistical Yearbook of the Republic of Serbia (2018): Chapter Agriculture. Statistical Office of the Republic of Serbia.

Wang, L., Yokoyama, K., Takahasi, H., Kase, N., Hanya, Y., ... \& Nishimura, K. (2001): Identification of species in Aspergillus section Flavi based on sequencing of the mitochondrial cytochrome b gene. Int. J. Food Microbiol., 71, 75-86.

White, T.J., Burns, T., Lee, S. \& TAYlor, J.W. (1990): Amplification and direct sequencing of fungal ribosomal RNA genes for phylogenetics. -in: InNis, M.A., Gelfald, D.H., Sninsky, J.J. \& White, T.J. (Eds) PCR protocol: A guide to methods and applications. Academic Press, New York, USA, pp. 315-322.

Open Access statement. This is an open-access article distributed under the terms of the Creative Commons Attribution-NonCommercial 4.0 International License (https://creativecommons.org/licenses/by-nc/4.0/), which permits unrestricted use, distribution, and reproduction in any medium for non-commercial purposes, provided the original author and source are credited, a link to the CC License is provided, and changes - if any - are indicated. 